\title{
The Language of Partition: A Study of the Narrative Structures of Selected Stories
}

\author{
Barnali Saha \\ Assistant Professor \\ Vivekananda School of English Studies \\ Vivekananda Institue of Professional Studies \\ New Delhi, India \\ barnali.saha@vips.edu
}

\begin{abstract}
The Partition of India in 1947 that resulted in the death and displacement of millions of people continues to inhabit the cognizance of the people of South Asia as a historical phenomenon laden with violence. Although the bequest of the Partition is palpable in episodes of religious tension, discourses on minority belonging, secularism, nation and nationalism in India, critical exploration of the phenomenon as a tension-ridden historical episode has largely been restricted. The present research paper deals with the stylistic aspects of a series of seven short fictional narratives from Bengal and Punjab. In this paper, the scholar talks about how the creative-imaginative representation of Partition has till date remained confined to the discussion of thematic aspects with the result that the elements of narration have remained insignificant in critical mediation. As such, the scholar addresses the gap in the genre of Partition studies by critically reading and stylistically scrutinizing the narrative elements of a series of selected Partition narratives to see how violence as a leitmotif in these seven selected fictional texts is documented.
\end{abstract}

Keywords: Partition, language, stories, Bengal partition, Punjab, violence 
And the words slide into the slots ordained by syntax, and glitter as with atmospheric dust with those impurities which we call meaning.

Anthony Burgess, Enderby, 406

The creative-imaginative representation of Partition has been generally projected as the unofficial counterpart of Partition historiography. With the deliberate task of replicating the morbid history of Partition in creative writing, the fiction-history parallelism between the two has till date remained confined to the discussion of thematic aspects, treating the elements of narration as insignificant for critical mediation. Considering the deliberate exclusion of the narrative aspects of creative texts on Partition as an obvious lacuna, the Paper would endeavor to read the story and discourse of a series of selected Partition narratives to see how violence as a leitmotif in such fictional texts is narratively documented.

The fictional projection of the reality of Partition is a deliberate subjective effort by an author whose inspired selection of words to emphasize narrative events and discourse instill meaning to his narrative project creating the dramatic effect that is integral to good literature. Therefore, studying the constructional devices of the discourse along with the story, which involves the consecutive sequence of events, enables a comprehensive understanding of the overall structure of a narrative text. For example in Intizar Hussain's short story "The City of Sorrow" the discourse involves a confused narrative order, chronological dislodgment, authorial commentary, and digressions which illustrate the overall confusion and trauma people experienced during the violent months of the Partition. The sphere of violent action in the story comprises the unnamed characters whose active encounter with violence creates a hermetically sealed fictional environment replicating the effect of massive Partition violence in the social field. Therefore, the discourse actively motivates the narrative events in illustrating a morphology of violence, which is the central concern in Hussain's story. 
Narrative Structure at a Glance:

Professional writers frequently customize the narrative discourse for particular effect in order to imitate reality in fictional terms more forcefully and to potentially affect the fabula, the story. In order to establish a vital link between narrative events and discourse, the paper would now read the narrative structure to establish the fact that in a narrative text discourse possesses equivalent potentiality with the line of events and existents, the raw material or the story. With the idea that it is discourse that radically infuses with its motifs and metaphors, symbolism and similes the narrative effect of a story, the paper would first illustrate the basics of narrative structure before reading their delineation in a selection of texts on Partition violence.

"Narratives are communications (between) implied authors and audiences... What is communicated is story, the formal content element of narrative" (Chatman 31). This "formal content" or "basic story stuff" (Chatman 19) is called motif in Russian formalist writings. Tomashevsky writes: "The fable [fabula] appears as a set of motives in their chronological succession, and from cause to effect, the subject appears as the set of the same motives, but according to the order which they respect in the work," (Tomashevsky 269). Further, the story "is communicated by the discourse, the formal expression element" (Chatman 31). Therefore, "each narrative has two parts: a story (historie), the content or chain of events (actions, happenings), plus what may be called existents (characters, items of setting); and a discourse (discours), that is the expression, the means by which the content is communicated" (Chatman 19). The discourse states the story through two kinds of statements_-process and statis. Process statements communicate action, they are "in the mode of Do or Happen" and may either report or enact "an event according to whether or not it is ...uttered as such by a narrator." (Chatman 32). Process statements that imitate reality directly through dialogue and those that imitate reality indirectly by summarizing narration correspond to the classical distinction of Mimesis 
(Showing) and Diegesis (Telling) that Plato put forward in The Republic. In contrast, stasis statements communicate the prevalent traits and identities of existents (characters or elements of setting), they may either classify or qualify and can be either directly mediated or unmediated (presenting vs. exposing). As a general rule, statements in a narrative text are mediated or interpreted by a narrator. A narrator may be a covert, a character in the story (Ashraf Siddiqui's "Rabeya Apa") or an invasive external party (Farkhanda Lodhi "Pieces of Flesh") or covert as in stories by Hemingway which include "dialogue and uncommented-upon action" (Chatman 33). Therefore, the narrator "when he appears, is a demonstrable, recognizable entity immanent to the narrative itself ... [who] actually tell[s] the story to an audience, no matter how minimally evoked his voice, or the audience's listening ear" (Chatman 33-34). Close to the heels of the narrator is the construction of the implied author who acts as the author's creative incarnation and whom the reader conceives by assumption from the approaches expressed in the fiction. The implied author in Wayne Booth's view “chooses, consciously or unconsciously, what we read; we infer him as an ideal, literary, created version of the real man; he is the sum of his own choices" in authorial style that allows an awareness of the author's stylistic norms, tone through which the author communicates his judgment of the presented material and technique which involves the artistry of the author. "It is only by distinguishing between the author and his implied image that we can avoid pointless and unverifiable talk about such qualities as 'sincerity' or 'seriousness' in the author." (Booth 74-5).

The author also creates an implied/postulated reader who is "in short, an image of himself and another image of his reader; he makes his reader, as he makes his second self, and the most successful reading is one in which the created selves, author and reader, can find complete agreement" ( Booth138). 


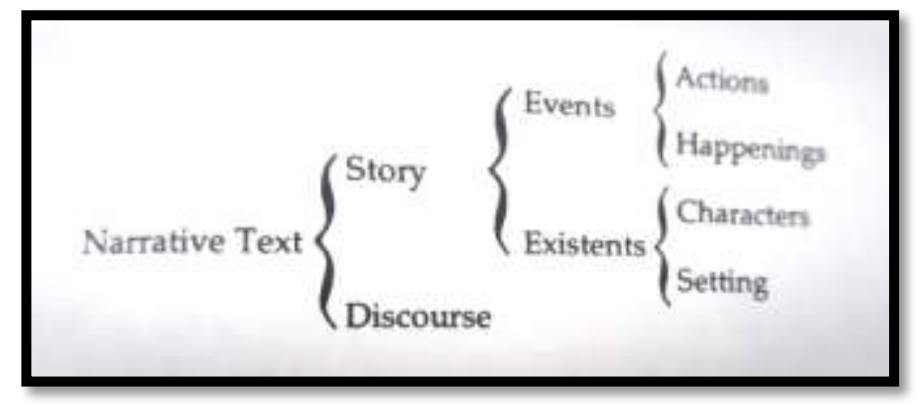

Figure 1: The Elements of Narrative Theory. Image Courtesy: Chatman, 19.

This representation of the elements of narration has been in vogue since the Poetics. "For Aristotle, the imitation of actions in the real world, praxis was seen as forming an argument, logos, from which were selected (and possibly rearranged) the units that formed the plot, mythos" (Chatman 19). The plot as a fundamental element of a narrative further involves the following basic elements:

- Exposition - The narrative transmission of contextual information necessary for readers' understanding.

- Crisis - The rise in story's action leading to moments of dramatic tension.

- Climax - The climactic moment of intense dramatic action in a story.

- Resolution or denouement - The aftermath of narrative climax that consolidates the loose ends of a story.

Apart from the plot, point of view is a vehicle to choose a particular narrative angle from which a narrative would be communicated. A story may involve an intradiegetic firstperson narration indelibly engaged in narrative proceedings, extradiegetic third-person narration by a narrator uninvolved in the narrative milieu, omniscient third-person narration by a sagacious narrator, limited omniscient narration by a narrator who can communicate the subconscious nuances of one or a few particular characters and finally, objective third-person 
narration by a narrator who acts as an objective reporter of incidents. Characters in such fictional representations may be either fully developed or life-like rounded characters possessing a variety of traits. Round characters are capable of surprising the readers and are agglomerate in nature not providing clear access to their nebulous mind. Round characters are ineffable and inimitable to a great extent. In contrast, flat characters are mono-directional, lack variety and are teleological in nature and are "easily recognizable with reference to familiar types in the real or fictive world" (Chatman 132). Flat characters, therefore, are typed characters who are rarely capable of great vivacity. While a character is the human agent that contributes to narrative effect, narrative setting is the spatial location (physical, historical, psychological) in a narrative that abstractedly exists in subterranean narrative level and that "sets the character off" in the usual figurative sense of the expression; it is the place and collection of objects 'against which' his actions and passions appropriately emerge" (Chatman 138-139). Thus setting contributes to the mood of the narrative.

Having discussed the basics of narrative structure, the paperwould now endeavor to read a series of texts on Partition to understand how the story and the discourse consolidate the overall dramatic effect of the narrative text. It will see how discourse uses different elements of linguistic style, rhetoric, syntax to actively contribute to the total narrative effect. It will especially study how mimesis (showing) diegesis, intradiegetic and extradiegetic narration, onomatopoeia, symbolism, etc., are used for especial literary effect in the communication of Partition violence.

Reading Partition with Reference to Narration of Violence in Selected Texts:

Text 1: "Dera Baba Nanak" by Joginder Paul

"When an incident breaks through the confines of the body and takes hold of the soul, it remains with it for a long time," The first sentence of the story "Dera Baba Nanak" by Joginder Paul" suggests a figurative point of view. The second sentence: "For this reason for 
nearly half a century now...I." and the third sentence, "Wouldn't it be better if I narrated the whole incident?" (Paul 268) suggest a first-person intradiegetic narrator from whose point of view the story is written. We know that "point of view is the physical space or ideological situation, or practical life orientation to which narrative events stand in relation" (Chatman 153), and this narrative depicts the story space through the anonymous first-person narrator. The second sentence literally sets the tone of the story and is important for consideration for a number of reasons: first, it depicts the dream/sense impressions of the narrator/implied author. These "pure sensations and images" (Chatman 187) are not translated by the mind into language and involve a direct quotation of the consciousness of the narrator. The piling up of images with truncated syntax: "first, right in front a herd of cows, behind them grubby rolypoly, radiant children and after them the aged, their beards snow white, aflutter...like birds and at its very end...I" (Paul 269) makes a first-person pronoun-reference to the thinking character who arranges dream elements to take us back (analepsis) to a time of trauma which had lodged itself figuratively in his brain. Here noun modifiers of nouns accompany adjectives for effect: "grubby roly-poly", "children radiant" "beards snow white". The simile in the end "their beards snow white, aflutter...like birds and at its very end...I" act as a powerful stylistic element directing our attention to the personal pronoun and its placement at the end of the sentence signifying the inconsequentiality of the narrator-character (the $I$ in the sentence) in the face of a cataclysmic time, the visual glimpses of which we get in the sentence. The first and the second sentence unequivocally set the narrative tone by suggesting that "trauma and time alter the way we recollect significant events" (Carey \& Hoffman 2018). The significant event the narrator talks about is Partition, the reference to which is made in the fourth sentence: "At the time of Partition, riots flared up throughout the country" (Paul 269). This short sentence, echoing the minimal structure of the previous sentence is used by Paul for "particular" effect, its very length here makes "effective juxtaposition with [the] longer more complicated" (Tufte 
10) second sentence. The "intuitive significance" (Chomsky 17) of the sentence is marked. By using a singles noun in its plural form "riots", the author documents the rampant pattern of violence that qualified the time of Partition. This sentence is therefore a "kernel", as Chomsky calls it (Chomsky 80), and serves in addition to its "utility as" a sentence, "a vital generative role" (Tufte 10). It is this juxtaposition of short sentences after long sentences throughout the text that provides "a telling emphasis" (Tufte 110).

The following paragraph starts the main story event (experience of migration during the Partition) in medias res. After the flashback (analepsis) into the narrator's sense impressions recorded in a series of associative dream elements suggesting the trauma of migration in the first paragraph, the author moves to a more matter-of-fact narration in the fourth paragraph in a deliberate effort to abstract his emotions from the narrative events he documents. The normal syntax of the sentences, their impersonal tone, creates a jarring note reinforcing our attention to the harrowing experience of migration. The use of the word "Hordes" in the first sentence suggests an expressional synonymy with the word "riots" used previously. These two words suggest groups, and actions performed (violent action in the case of riots) in groups respectively. Both the expressions - "Hordes" signifying a large group of people and "riots" meaning violent civil disorder executed by a group_-point out a lack of individualism in both these actions: riots are performed by hordes of people where all the faces involved form tessellated pieces together completing a puzzle in totality. It the numbers, the quality, the sheer force of totality that count in their instance. Partition violence thus, the author seems to suggest, involved victims and perpetrators who were part of groups, and consequently, lacked individuality. This assumption is deepened by the author's anonymity. In this paragraph the author documents his experience as a migrant traveling from Sialkot to Dera Baba Nanak by train. The whole story revolves around the sense-impressions he receives during the journey "[f]rom the dizzying stream of incoming perceptions ... [the] sights, sounds, sensations and 
emotions that [the brain] deem[ed] important or novel," and therefore worth preserving (Carey \& Hoffman 2018). Here the author uses a single question to set "an agenda for what is to follow" (Tufte 248) in the next line and in the following paragraph. The coherent parallelism of signification in the penultimate and the ultimate sentence (one short and interrogative, another long and expressive respectively) qualifies the author's encounter with violence. The repetition of the word dead create an insistence to reinforce the moribund nature of the multitude of migrants who were physically and emotionally so enervated that they were as good as dead. The documentation of violence involves the use of antithesis as the figure of speech to establish the actual condition of the sufferers of violence: "wherever the train stopped, we the dead would begin to breathe in fear of having reached the end of the other world, where in seconds 'they' would barge in raising slogans and shred our souls to bits along with our bodies" (Paul 269). The piling up of verbs "barge in" (phrasal verb), "raise", "shred" indicate a deliberate association of actions which together precipitated the effect of violence on the victims. The contingency of such acts of violence, the author seems to suggest in the clause, was rife, as we can see in the following paragraph. The emphasis on the word "they" within inverted commas to signify the other community and the use of the word other in the same sentence is worth noting. The locution "wherever the train stopped, we the dead would begin to breathe in fear of having reached the end of the other world, where in seconds 'they' would barge in raising slogans and shred our souls to bits along with our bodies" performs the illocution of predicting (violence) and serves the perlocution of frightening the implied and actual readers.

The theme of violence is further developed in the next paragraph where the author discards (unconsciously, it seems) his matter-of-fact impersonal style of narration suggesting that Partition violence has too palpable an impact on a victim/witness that its recollection is necessarily a mental reconstruction of the actual emotive experience such that an abstraction 
of the self from such a recollection is impossible, if not improbable. The truncated syntax“"brief phrases separated by three elliptical dots"” (Quoted in Chatman 188) returns here to suggest the omnipresence of the violent impressions the author gathered during his journey on the fateful train to Dera Baba Nanak. Here we see a controlled association of visual elements, sense impressions that reconstruct for the author a visual summary of the traumatic time he narrates: "a limb here, another there; there a lump of heart, a bunched-up woman's breast, here a shriveled penis, so shriveled one wondered whether it belonged to a Hindu and a Muslim" (Paul 269). The imagery here is a right-branching (cumulative) of visual elements as perceived by the movement of the narrator's eye. The author here shows a scene of violence by pairing up images of dismembered body parts (breasts, genitals). The use of the adjective modifier "shriveled" in the sentence, the noun "lump" together with the phrasal verb "bunched up" attributively used to modify the images of a cut-up woman's breast, a dismembered human heart and a castrated pen respectively add to the visual horror the image the writer/narrator perceived and effectively transmits the revulsion the narrator experienced to the implied/real read via the discourse. The scene is static, but add texture and density to the effect of the narrative text. The vison suggests that Dera Baba Nanak despite its allusion to the supreme Sikh being, Guru Nanak, would be as dystopic a place as any other Partition inflicted zone. The author inculpates both Muslims and Hindus/Sikhs for the violence and suggests by showing us a shriveled up dismembered castrated penis bearing no communal identification as being a possible property of a person belonging to either community. Violence, in Paul's view, is selfdestructive.

From the scene of general violence the narrator witnessed, the narrative focus shifts to the protagonist in the story, a mad man: "Along with us had com a raving mad...lunatic...a nameless crazy fellow," (Paul 270). As if to comment on the insanity of grafting somatically absent national borders to divide people who had a common cultural legacy, the author 
established the character of the crazed man. The symbolic significance of the character, as well as the syntactic symbolism of the discourse representing him are marked. First, like a Shakespearean Fool, a mad man is an "all-licensed" detractor who "suggests [by his presence and actions] that there is ambiguity in the words, wisdom and folly," (Wilson qtd in Knight 256). Second, considering that Knight defines madness as the "breaking of that which differentiates man from beast," "the disjointing of mind by the tug of two conflicting principles" (Knight 184, 205), the mad man in the story symbolizes the snapping of reason by the Partition, which is, in the author's view an act of bureaucratic lunacy itself. The rushed, paratactic structure of the sentence introducing the anonymous mad man becomes a simulation of the protagonist's situation as an un-reasonable entity. The grammatical arrangement of the words in the sentence: "Along with us had com a raving mad...lunatic...a nameless crazy fellow," (Bhalla 270) reflect the erratic motion of the mad man's thought, the rapid change of ideas, and his total unreasonableness. Here the writer has used a sentence structure that "mimics the particular action the sentence describes" (Tufte 253). A line of interpretation that is suggested by the anonymity of the mad man, in contrast to Manto's legendary madcap protagonist Bishan Singh in his short story "Toba Tek Singh," is that both the anonymous narrator and the unnamed mad man are not in fact separate individuals; it is their anonymity that constructs them as one single psychological entity. The narrator and the mad man can thus be seen as "two decomposed parts of a single self," (Rocha 13). This leads us to the idea that the Joginder Paul in the story "splits a character up into two personages, which taken separately are not completely understandable and do not become so until they are brought together once more into a unity." Thus the narrator and the mad man are "like two disunited parts of a psychical individual" (Freud 137).

The discourse in the following section of the narrative further emphasizes the idea that the mad man and the narrator are in fact "two disunited parts of a psychical individual" (ibid). 
Once introduced, the mad man and his antics takeover the story events and he becomes the main existent. The discourse uses an alternation of showing and telling to display his actions and suggest symbolically the irony of the Partition project. To display the labile nature of the mad man's personality, the narrator talks about the incident of his discovering a severed penis. The sentence structure here must be noted. This short paragraph uses a series of action words like the nonfinite verbs screaming, loosening (present participle) to animate the syntactic structure and direct our attention to the frantic energy the mad man displays upon seeing the severed penis. The use of exclamation in the paragraph in three separate sentences and the repetition of the word look instill a melodramatic effect: "The crazy fellow would start screaming 'Don't kill me. I am a Hindu, look!' He would lift up his shirt and start loosening his pajama strings. 'Look! Look!' and at other times he shouted 'Don't kill me. I am a Muslim, look...look!" The strong feeling of the mad man on his dubious religious identity, the inverted nature of his presence and the vivid intensity. Repetition of the word look, the recurrence of ellipses and the parallel structures of the two following sentences with "similar sounds and words” (Tufte 234): 'Don't kill me. I am a Hindu, look!' and 'Don't kill me. I am a Hindu, look!'(Paul 270) contribute a calculated rhythm to the subject matter of the story that criticizes Partition and the trauma it induces, and puts in sharp relief the idiosyncrasy of the mad man as well as the eccentricity of the violent time. That the man cannot differentiate between the religious identity of a Hindu and Muslim and fails to realize the importance of this distinction in the context of gendered Partition violence on the male body is a critique of the random acts of "[f]orced circumcision, shaving facial and head hair (for Sikh men), and shaving off the Hindu Brahmin's traditional short, plaited hair" (Daiya 69-70) that comprised the usual practices of violence on the male body during the Partition.

"Syntax accomplishes most of the symbolizing" (Tufte 255) in this paragraph and punctuate the actions that follow. Also, the author uses various synonyms which are 
semantically important in heightening the story effect. For the word mad the words "lunatic," "crazy fellow," "mad cap" do more than renaming the mad man; they delineate and magnify the character of the mad man as a caricature "with successive levels of detail making the picture more exact" (Tufte 194).

The dialogue between the mad man and the rest of the crowd including the narrator who jestingly approach him upon his discovery of the severed penis underline the absurdity of the narrative context as well as the dialogue between them and define the stretch of violence in a dystopic post-Partition society where words have lost their putative communicative role.

The use of truncated syntax and the exclamatory as common denominators in the speeches of the mad man create a balance with their repetition heightening his idiosyncrasies as well as directing our attention with their deliberate and faulty parallelism to the extreme nature of his tangle of ideas. Thus the discourse effectively adapts to the narrative content by a facile repetition of rhetorical elements to suggest without equivocation the distorted nature of the protagonist's thoughts and actions. That the author had initially used truncated syntax to deliver the interior ideas of the narrator and later uses it to depict the words spoken by the mad man emphasizes the point made earlier that the narrator and the mad man are in fact "two disunited parts of a psychical individual" (Freud 137), the psychical individual being the author.

Considering that "Repetition" constitutes the essence of "prose rhythm... Many types of parallel arrangement, of balance and calculated imbalance in phrase and clause, of repetition and ellipses, pairings, catalogings, contrast and other groupings...can contribute to the unique rhythms of any kind of prose," (Tufte 234), Joginder Paul uses a repetition of ellipses and exclamatory to distinguish the mad man's speech. The combination, however, is used to relate the speaker's narration of events relating to the mad man as well, thus heightening his psychical synonymy with the lunatic. The author uses the combination in a paragraph that narrates 
(diegesis) from the point of view of first person narrator, the actions of the mad man who had run away at the sight of the monster like figure he had created with the tessellated body parts he had found lying around: "While I was watching him, he suddenly sprang back up in fear and looked horror struck at the image he had created...A terrifying shape of a monster with distorted limbs as though ready to dig his teeth into him" (Paul 271). The use of verbs and adjective modifiers to signify the frantic action of the unbalanced lunatic like sprang back (verb), horror-struck (adjective) transmit the frantic rhythm of his action.

The later section of the story after the mad man had run away upon his encounter with the Frankenstein-like monster he had created is entirely diegetic and follows the first-person point of view of the narrator. The truncated syntax that qualified his initial subconscious activity in the starting of the story suggesting his mental activity of remembering the incident he narrates is used once again as we again get a panoramic view of the narrator's subconscious.

The antepenultimate paragraph echoes the first paragraph in that the images we glimpsed at therein are repeated and we know that the narrator has reached the climactic point of the story and is face to face with the very scene that would stay with him forever as a symbol of the trauma of Partition. Since "[r] ecollection is always a reconstruction," (McNally qtd in Carey and Hoffmann, NY Times), it is interesting that the discourse in this paragraph reconstructs the recollected images of the first paragraph. The passage describes the refugee column the narrator sees passing by. It is in the direction of this caravan that he had seen the mad man run. The author uses single adverbs and adverbial connectors to describe a unity of spatial order and uses directions to designate movement across space: "First, in front. there were robust white and brown cows. Behind the cows...Behind the children...And after them..." (Paul 272). The paragraph is intensely visual and uses verb and adjective modifiers for photographic effect. The use of the words half and full is especially interesting for the balancing effect the sentence seeks to project: "In their throats the cry of Allah-O-Akbar stuck half-way, 
the cry which would be a full-throated one, the moment they crossed the border..." (Paul 272). The parallelism emphasizes the inevitable progression of the Muslim call of invocation of Allah from a mumbling call laden with dread a prayer that necessarily signifies the collective fear of the members of the caravan crossing a dangerous Hindu territory. Once the temporal progression is made, the slogan would reach its crescendo in celebration and relief. The author depicts this movement from fear to exhalation through the use of the paired construction involving two words half-way/ and full-throated, both adjectives. It is interesting to note how the idea of impending violence is communicated by the author by the use of three words: "Allah-O-Akbar," "half" and "full”. During the Partition "Communal animosity began to be expressed in terms of belligerent slogans and war cries from the rooftops. The Muslims would shout "Nahra-e-Takbir, Allah o Akbar". This was followed by screams of "Har, Har Mahdev" by the Hindus and "Jo Bole So Nihal, Sat Sri Akal" by the Sikhs. Each chorus dragged on only to be followed by the other side prolonging its menacing recitation of the religious call to arms" (Ahmed 16). The passage involves the reader reading out the symbolic significance of the terms used and their contextual importance.

The penultimate and the ultimate paragraph uses interrogation, exclamation and onomatopoeia. "Aree...who is this? Walking along the side of a frail and fatigued mother, holding her young man with great care, fully alert and in his sense, who he was! He was the mad man!" The paragraph uses two direct questions one with a mark of interrogation and another with an exclamation mark to communicate a sense of urgency "to the narrative, serving to raise the dramatic pitch and ...heighten the suspense of the story" (Tufte 205). The paragraph focuses on the unresolved question at hand and its answer. A series of adjective modifiers lead the sentence to the climactic moment of suspense when the author delivers the answer. The alternation of a long and short sentence adds to the effect of the construction. 
In the last paragraph the use of exclamation produces the emotional emphasis that sets the tone of the paragraph. The ending paragraph emphasizes the effect of the whole story and involves the reader reading out its symbolic significance. The paragraph begins with the narrator addressing the guards and trying to direct their attention to the figure of the madman. He tries to convince them that he is a Hindu and is moving in the wrong direction with the Muslim caravan. We can very well imagine the contingency of violence that awaits the man upon crossing the border and after the discovery of his religious identity. Our anxiety is reflected by the truncated speech of the narrator. The use of ellipses creates the halting effect. The author uses an alternation of mimesis and diegesis in the paragraph. The suspect nature of the man's religious identity is stressed. The ending is open-ended. The recoding of the narrator's perceptual details as he directs the guards' attention toward the mad man adds a visual vitality to the ending with is paired by the onomatopoeia that emphasizes the dramatic effect. Exasperated by the narrator's unending implorations, the guards utter "Sh...sh" to hush him up echoing the sentiments of those who decisions realized the Partition but who were apathetic to the woes of the millions, like the mad man and the narrator, more obvious in the end as mirror images of each other, whose lives the Partition mutilated for good.

The story is a critique of politics that resulted in the Partition of India and is narratively rich in terms of the syntactic devises the discourse uses to bring out the central effect of the story. Violence is here narrated by omission; we are presented the images which compose the after effects of violence that creates the impression of horror that Partition signifies for the author, and by extension, the readers with whom he actively communicates.

Text 2: “An Ilish Story” by Khademul Islam

Khademul Islam's short story captures the violence of the Partition by investing in the narrator's alimentary anxiety linked to his unconscious coupling of the physical act of scaling a fish with communal violence. The discourse creates a dramatic effect by placing sentences 
depicting the actual act of scaling and cutting a fish, a pedestrian act common in Bengali households, with a narration of communal violence by the aged matriarch, the fundamental character in the story. The story is written from the point of view of an intradiegetic first-person narrator who perceives the dramatic action and narrates it. Direct tagged sentences in present tense alternate with narrative description of scaling the Hilsa in implicit terms creating a distinct rhythmic effect. We see three characters in the story: the narrator, his mother and his grandmother. The narrative focus rests on the septuagenarian who has come from Chittagong bearing an "Ilish mach" (hilsa fish), a treat for her grandchildren. The setting is 1972, postPartition Bangladesh.

The story begins with a statis statement identifying the narrative time. The first paragraph rests on several unmediated statis statements recognizing the main existent, the grandmother. The author depicts a halcyon domestic scene: "A brilliant mid-morning on aback verandah in Reyer Bazaar. My mother and I are comfortably perched on old cane moras watching my maternal grandmother about to gut a fish" (Islam 433). Two words: the adjective brilliant and adverb comfortably creates an illusion of restful home life. The author uses a rightbranching cumulative sentence to introduce the grandmother. The discourse is an enactment of the narrator's visual perception of the old woman: "She is seated behind the dark, curved blade of an old boti, holding down its scarred wooden stock with her right foot" (Islam 433). The sentence uses adjective additions like dark, curved, old, scarred to elaborate the description not of the old woman, but the cutting instrument she would use to gut the hilsa. In the short sentence following it: "The sharpened edge of the blade glints" (ibid) the two words sharpened (past participle of verb sharpen) and glints (verb) provide a telling emphasis on the importance of the cutting instrument in the story. The two sentences and the statis statements depicting the cast a chilling note of foreboding of the story to come. It is especially interesting to note that while the first paragraph uses the appositive characteristics of adjective additions to add to the 
descriptive characteristics of the paraphernalia re required for gutting and dismembering the fish, the descriptive details of the old woman wielding the instrument are limited. We are simply informed that she is a "small" (adjective) woman wearing a starched white sari who has come down from Chittagong to meet her grandchildren, bearing an exotic fish, a Hilsa from the famed Padma River, a delicacy if ever there was one.

"1971 is 1947 all over again" (Islam 434). This short, tagged mimetic sentence by the grandmother is important for the emphasis it tends to direct on the phrase "all over again". The sentence directs our attention to the violence of 1947 to the "the war, the refugees and the subsequent release from the daily horror" (Islam 434) and their echo in 1971 Bangladesh Liberation War. The old woman does not elaborate on this point and the discourse is an enactment of her act of gutting the fish. "Fish scales fly high in all directions and a few sizzles upward, float momentarily at the top of their arc, aquamarine and topaz spangles, before gliding down on the cement," (Islam 434). The power of the sentence, offering as it does the impression of specificity of the act of scaling a fish, derives from this kind of deliberate showing that creates a "lesser" (Genette 162) narrative distance and imparts a vividness by presenting "everything that happened" (Toolan 134). The next few sentences in the paragraph are diegetic and the symbolic significance of the flying fish scales is realized here as the sight brings to the narrator's mind memories of 1947 Partition which resulted in people "flying pell-mell” (Islam 434). "In 1947, during the Partition, my grandparents had fled from Calcutta (now Kolkata) along with other Muslims. Whole paras (neighborhoods) slaughtered in a day; my mother had said. Babies thrown over walls. Trembling adults and children fleeing pell-mell" (Islam 434). The antithesis between the former mimetic sentence and the latter diegetic is stark. While the former sentence rests on its visual appeal, the latter is a piling up of indirect information gathered from the narrator's mother. From the highly visual long sentence that generates the 
symbolics of the movement of the fish scales, we are directed to the disjointed immediacy of Partition experience that contrasts with the smooth progression of the mimetic former line.

“'Down the road from our house,' she continues with an upward glance at us, the irises of her eyes black as amulet string, 'there was a Hindu household.' Her hands are betel-nut brown, turmeric stained, a working matriarch's hands, ceaselessly directing, ladling tucking in, handing out the daily bazaar money, smoothing out, folding a paan leaf, picking” (Islam 434).

The paragraph involves a narrative pause. The story time stops, and thick descriptions of the matriarch's hands takes over. The author, intending to heathen the dramatic effect, uses a series of action words (verbs) to break up the dialogue. The simple sentence: "Down the road from our house, there was a Hindu household" (Islam 434), states "in simple terms the central idea of the paragraph" (Tufte 24). Lodged among the thick descriptions of the granny's hands, this line acts as a topic sentence in the narrative and acts as a kernel. Kernels are "narrative moments that give rise to cruxes in the direction taken by events. They are nodes or hinges in the structure, branching points which force a movement into one of two (or more) possible paths," (Chatman 53). The dialogue creates an atmosphere of suspense which is "achieved in part by foreshadowing — hints of what is to come" (Barnet, Berman and Burto 83-84).The path here indicated by the dialogue is one of violence, as suggested, symbolically, by the dismemberment of the fish narrated in great detail as well as the topic of discussion between the grandmother, the first-person narrator and his mother, the horrors unleashed by 1971 Bangladesh Liberation War. The repetition of word taja (fresh) by the grandmother later in the story further focus the suspense on her narrative about the Hindu family. Here foreshadowing takes the "form of inferences drawn from existents" (Chatman 60) that project a story of violence, which is still fresh taja in the grandmother's mind.

After several paragraphs of thick descriptions of gutting the fish which accentuate the suspense, the grandmother speaks: "'One night — well, it was two o' clock in the morning, we 
heard screaming and shouts of narai takbir,' she continues, referring to the Muslim rallying cry during the 1947 communal riots," (Islam 435). The logic of the story is directed toward reinstating the idea put forward by the grandmother early on that " 1971 was 1947 all over again"” (Islam 434). The rivalries and aggressions between the Hindus and the Muslims remained seems to have remained unmitigated by the violence and had recurred in 1971 with renewed vigor.

That the narai takbir, the Muslim religious call Allah-hu-Akbar, that in the context of the Partition of 1947 had become a loaded signifier signifying "the Muslim rallying cry" before a communal attack on the Hindus is repeated in 1971 in a similar context of communal violence suggests its continued significance as a call of aggression. In the milieu of communal violence, the element of religiosity integral to the narai takbir, took on a different meaning. The call doubled as a cry for violent action against a target, a victim. It was this call that unified the Muslim aggressors in 1947, granting the group a cohesion as they integrated against the enemy community, the Hindus/Sikhs. That the similar call is repeated in a synonymous circumstance nearly twenty-four years later portends a contingency of violence in the vicinity.

"“The next morning we heard that they had been attacked and killed," she says with another glance at us, putting back the rimless spectacles with the back of her right hand, careful to keep the fingers clear of the lenses. 'They said that the maulavi had himself slit their throats"' (Islam 435). The act of killing the Hindus by slitting their throats is problematic. It symbolically resembles the Muslim act of sacrificing animals by kosher (halal) on Quarbani Eid. The author's insistence that the Hindus, by virtue of the scapegoat mechanism, were the "transcendental signifier" (Collins 12) of evil upon whose "murder...all [Muslim] culture rests" (ibid) is interesting in bringing to light the status of the victim as a signifier "Standing at once for war and peace, life and death" (Collins 12). The very destruction of the Hindus in ritualistic terms (slitting of throats) by the maulvi (the priest) underlines the human penchant 
"for reproducing the language of the sacred by substituting, in ritual, new victims for the original victim, in order to assure the maintenance of that miraculous peace," (Girard 103). The story is an irony in showing how despite the death of the victim, (the Hindus, in this case), "designed to circumvent the mimetic rivalries or vengeful cycles...against twins [Muslims against Muslims as we saw in 1971]" (Collins 12-13) the crisis could not be averted and 1971 turned out to be "1947 all over again" (Islam 434). Myth and ritual that construct the prophylactic power of the sacrifice of a victim (human in communal violence an animal in ritual violence) is critiqued by the author in his depiction of the two major characters: the grandmother, a wily septuagenarian who dismembers a dead fish with a uncharacteristic violence and a maulvi, a member of a Peace Committee, a figure of supposed religious piety who performs blood sacrifices for the sake of harmony among Muslims, but in actuality unleashes a cycle of vicious communal violence that repeats itself over and over again.

The ending of the story is a further critique of the violence of sacrifice as the hilsa, the supposed delicacy, served for lunch becomes for the narrator the hypothecated symbol of violence. In its elaborate and systematic gutting and dismemberment that can be almost termed ritualistic, the narrator sees the communal scapegoat, the victim Hindu and others like them who are cut and dismembered during communal violence. The story ends with a scene where the story time equals` the discourse time. The scene incorporates into the narrative text the principles of drama and uses "dialogue and overt physical action of relatively short duration" (Chatman 72) for emphasis.

"'You are not eating the ilish?"

"Not today."

"Can't sort out the bones, eh?"

"No, I think I need more time."

A pause and another round of ilish jhol (curry broth) for everybody, except me. 
"You are hardly eating anything at all."

"I am not very hungry."

"So how do you like Dhaka?"

"Bhalo (good) khub bhalo (very good)"” (Islam 436-437).

The direct untagged speech indicate the context in which the two characters (the overt firstperson intradiegetic narrator and his mother) communicate. Without equivocation, the freestyle narration concentrates on the symbolism of the fish as a leitmotif of violence. In this context, it is interesting to remember that "psychoanalysis believes that crucial to recovering from an experience of trauma is the capacity and willingness to incorporate that traumatic event inside one's self as an indispensable piece of personal history and identity" (Horowitz 6). In the story, "the narrative is inextricably entwined with memory and the process of remembering, the greater one's ability to "make story" out of trauma, which is defined differently for each protagonist, the more likely s/he is to regain control of her or his life after that trauma" (ibid). While the grandmother has come to terms with her traumatic experience and is able to narrate the story of communal violence, the narrator finds it difficult to come to terms with it. Having witnessed the violence second hand, through the gutting of a fish, he finds the post-traumatic stress overwhelming. Thus, when the narrator's mother asks him if he is having difficulty is deboning the fish, he replies that he needs more time, suggesting the narrator's continued preoccupation with the story of communal violence narrated by the grandmother. The narrator's rejection of the delicacy is a sublimation of his anger and despair at his ineptitude in thwarting an act of violence, so mundane, so pedestrian in its effect that nobody except him is affected by it.

The scene is mimetic and relies entirely on showing rather than telling. The narrator's mother understands his dilemma and steers the communication in a different direction: "'So how do you like Dhaka?" 
"Bhalo (good) khub bhalo (very good)"” (Islam 436-437).

The syntax in the last sentence travesties a weary repetition of cultural niceties generally engaged by Bengalis when they meet and greet in public. It symbolizes the author's preoccupation with another topic, communal violence and the Partition perhaps, the symbolic bones that he finds difficult to disentangle at the moment. The story is, therefore, a trenchant critique of communal violence in which transverse descriptions of gutting a fish alternate with simple sentences narrating a tale of intercommunal violence to demonstrate a symbolic hypothecation wherein the act of descaling the fish qualifies the act of communal violence that is merely narrated and non-described creating a unique dramatic effect.

Conclusion:

The paper has read two short stories on Partition with the intention of studying the how language and rhetorical devices are used in narrative discourse to communicate violence in particular and Partition in general. The paper has mainly concerned itself with the study of language in these texts as the most important element, shared by all narrative texts, performing the dual function of acting as the medium and as the article of exemplification. Considering the fact that language is the principal intermediate of representation in the narrative texts, the paper highlights how language becomes an inextricable part of the imagined world created by the narratives. It also pays considerable attention to the stylistic techniques the stories use in the analysis. As such, the paper studied how showing and telling (mimesis and diegesis), speech representation (speech reports, tagged direct speech, indirect speech), word order, metaphor and simile, parts of speech, deliberate parallelism, syntactic symbolism are common devices the stories have used to communicate an atmosphere of violence. As such, the particular characteristics of language and style discussed in this paper direct attention to their special relevance narrative texts on Partition to justify the insertion of stylistic inquiries in critical analysis of the narrative texts on Partition. 


\section{Works Cited}

Booth, Wayne. The Rhetoric of Fiction, Second edition, University of Chicago Press, 1983.

Chatman, Seymour B. Story and Discourse: Narrative Structure in Fiction and Film. , 1978.

Benedict Carey and Jan Hoffmann, "They Say Sexual Assault, Kavanaugh Says It Never Happened: Sifting Truth From Memory, How trauma and time alter the way we recollect significant events." New York Times (Sept. 25, 2018). Accessed on 13.8.2019.

Chomsky, Noam. Aspects of the Theory of Syntax. Harvard University Press, 1965.

Collins, Brian. The Head Beneath the Altar: Hindu Mythology and the Critique of Sacrifice. Michigan State University Press, 2014.

Daiya, Kavita. Violent Belongings: Partition, Gender, and National Culture in Postcolonial India. Philadelphia: Temple University Press, 2008.

Freud, Sigmund. "Some Character-types met with in Psychoanalytical Work," MacbethCasebook Series: A Selection of Critical Essays, ed. John Wain. The Macmillan Press, Ltd., 1968.

Genette, Gérard. Narrative Discourse Revisited. Cornell UP. ([1983] 1988).

Genette, Gérard. Narrative Discourse. An Essay in Method. Cornell UP, ([1972] 1980).

Horowitz MJ. American Psychiatric Association Task Force on Treatments of Psychiatric Disorders, editor. Treatments of psychiatric disorders: A task force report of the American Psychiatric Association. Washington, DC: American Psychiatric Association; 1989. Posttraumatic Stress Disorder; pp. 2065-2082.

Islam, Khademul. “An Ilish Story”. Stories About the Partition of India, Vol IV edited by Alok Bhalla. Manohar, 2012.

Knight, G. Wilson. The Wheel of Fire. Methuen \& Co., 1930. 
Paul, Joginder. "Dera Baba Nanak" translated from Urdu by Naghma Zafir. Stories About the Partition of India, Vol IV edited by Alok Bhalla. Manohar, 2012.

Kessler Rocha, Ana Maria. “Madness in Shakespeare’s Major Tragedies: A Tentative Analysis towards a Laingian Interpretation," Universidade Federal de Santa Catarina,1980,repositorio.ufsc.br/bitstream/handle/123456789/106138/321993.pdf?se quence $=1$.

Toolan, Michael. Narrative: A Critical Linguistic Introduction. Routledge, ([1988] 2001).

Shklovsky, Victor, Boris Tomashevsky, Boris Eichenbaum, Lee T. Lemon, and Marion J. Reis. Russian Formalist Criticism: Four Essays. Lincoln, Neb: University of Nebraska Press, 1965.

Tufte, Virginia. Artful Sentences: Syntax as Style. Graphics Press LLC, 2006. 